ABSTRACT. Szkłowski Wiktor, Trzecia fabryka [Third Factory]. „Przestrzenie Teorii” 23. Poznań 2015, Adam Mickiewicz University Press, pp. 185-216. ISBN 978-83-232-2920-9. ISSN 16446763. DOI 10.14746/pt.2015.23.12.

Victor Shklovsky's Third Factory is the third part of the so-called "autobiographical trilogy", which was first published in 1926, i.e. after Shklovsky's return from abroad, following his unwilling emigration. As a literary work, it is not easily classified. In part, it is a memoir of the three "factories" that influenced Shklovki's development both as a writer and a witness of his time. In addition to fictional and biographical elements, Third Factory also includes anecdotes about writers, literary critics and theorists (e.g. Roman Jakobson, Yuri Tynianov, Boris Eikhenbaum, and Y. Polivanov) as well as letters and memoirs, which are published here in a Polish translation for the first time.

[Trzecia fabryka to ostatnia część tzw. trylogii autobiograficznej Wiktora Szkłowskiego. Składające się na nią części (Podróż sentymentalna, ZOO. Listy nie o miłości, Trzecia fabryka) zostaną wydane pod wspólnym tytułem nadanym przez wydawcę rosyjskiego Jeszcze nie wszystko skończone... nakładem Wydawnictwa Akademickiego SEDNO w koedycji z Centrum Polsko-Rosyjskiego Dialogu i Porozumienia w 2014 roku. Wydanie wczesnej prozy Wiktora Szkłowskiego jest częścią projektu wydawniczego przygotowanego przez Danutę Ulicką, a realizowanego przez SEDNO i Centrum. Do tej pory ukazały się dwie pozycje z planowanych dziesięciu: Na całe życie. Listy 1910-1954 Olgi Freidenberg i Borysa Pasternaka w tłumaczeniu Wincentego Grajewskiego oraz rozprawa Michaiła Robinsona Losy elity akademickiej. Rosyjska slawistyka od 1917 roku do początku lat 30. w przekładzie Mirosława Skarzyńskiego. Program wydawniczy obejmuje nietłumaczone wcześniej na język polski publikacje memuarystyczno-wspomnieniowe i monograficzne przedstawiające wybitne zjawiska i postaci humanistyki, sztuki i kultury Rosji XX wieku.

Tłumaczenie fragmentów książki na podstawie jej reedycji z 2002 roku (W. Szkłowski, Jeszczo niczego nie koncziłos..., red. A. Gałuszkin, Moskwa 2002) podług pierwszego pełnego wydania z 1926 roku, uzupełnionego przez redaktora rosyjskiego nieznacznymi poprawkami zachowanymi w rękopisie z zecerni i w korektach.

Pierwszy szkic Trzeciej fabryki powstał latem 1925 roku. Szkłowski pracował nad książką jesienią i zimą 1925 roku oraz zimą 1926 roku. Skończył ją w marcu 1926 roku - uwaga tłumaczki.] 


\section{Pierwsza fabryka}

\section{O CZERWONYM SŁONIKU}

Czerwony słoniku, zabaweczko mojego syna, wpuszczam cię do mojej książki pierwszego, żeby ktoś inny nie poczuł się najważniejszy. Czerwony słonik piszczy. Wszystkie gumowe zabawki piszczą, bo inaczej - po co uchodziłoby z nich powietrze?

No więc, na przekór Brehmowi ${ }^{1}$, czerwony słonik piszczy. I ja też piszczę w swoim wysokim gnieździe nad Arbatem².

Rzadko który ptak doleci do mnie ${ }^{3}$ bez zadyszki. Oduczyłem się w swoim gnieździe robić głębokie oddechy.

Mój syn się śmieje.

Zaśmiał się, kiedy po raz pierwszy zobaczył konia: myślał, że ten dla żartu sprawił sobie cztery nogi i długi pysk.

Odcisnęły się na nas formy różnych matryc, ale jeśli przycisnąć mocniej, to mówimy jednym głosem.

Czerwony słoniku, odsuń się, chcę zobaczyć życie na serio i coś mu powiedzieć głosem własnym, a nie piszczącej zabawki.

Tu kończy się felieton.

\section{PISZE O TYM, ŻE BYT OKREŚLA ŚWIADOMOŚĆ, A SUMIENIE POZOSTAJE NIEDOOKREŚLONE}

Mark Twain przez całe życie pisał podwójne listy ${ }^{4}$ - jeden wysyłał do adresata, a drugi zostawiał dla siebie, i w nim pisał to, co myślał.

Puszkin też pisał najpierw list na brudno.

Ostatnie dni jesieni. Szeleszczą zasychającymi liśćmi przy Skatiertnym, Czasznikowym, Chlebnym ${ }^{5}$ (jak gdyby ktoś zamiatał odrzucone rękopisy). Słychać grę na skrzypcach ${ }^{6}$. Nie mam prawa tego ukrywać.

1 [Alfred Edmund Brehm (1829-1884) - niemiecki zoolog i podróżnik, autor wielokrotnie wydawanej książki Życie zwierząt (Tierleben, 1864-1869), która przyniosła mu międzynarodową sławę oraz przydomek „ojciec zwierząt” - przyp. tłum.; tu i dalej przypisy w nawiasie kwadratowym pochodzą od tłumaczki, pozostałe - od redaktora rosyjskiego.]

2 W latach 1924-1927 Szkłowski wraz z rodziną mieszkał w Moskwie przy Skatiertnym Pierieułku 22/31a, na siódmym piętrze dawnej kamienicy czynszowej.

${ }^{3}$ Aluzja do Strasznej zemsty Gogola: „rzadko który ptak doleci aż do połowy Dniepru!” [cyt. w przekładzie Cz. Jastrzębca-Kozłowskiego].

${ }^{4}$ Zachowało się wiele niewysłanych listów M. Twaina, w licznych wariantach.

${ }^{5}$ Czasznikow Pierieułok połączył się z ulicą Powarską, a Chlebny Pierieułok obecnie nie istnieje.

${ }^{6}$ Chodzi zapewne o Borisa Ejchenbauma (zob. dalej: List do Tynianowa) z przypisem do cytatu z Rewizora Nikołaja Gogola „Iwan Kiriłowicz bardzo utył i ciągle gra na skrzyp- 
$\mathrm{Na}$ zielonym wirażu latarń, kadr za kadrem, przesuwają się ulice. Idę - i śpiewam jak romans:

Nie, ty wcale nie jesteś mi droga, Miłośnice nie bywaja takie?

W redakcjach ścianki działowe są z dykty. Myśli w przegródkach. Nie zdarza się, żebym wyszedłszy skądkolwiek, nie poczuł się lepiej na ulicy.

Przeciekam jak sparciały gumowy szlauch. Książka będzie nosić tytuł:

$$
\text { "Trzecia fabryka”. }
$$

Po pierwsze, pracuję w Trzeciej Fabryce Goskina ${ }^{8}$.

Po drugie, łatwo wytłumaczyć tytuł książki. Pierwszą fabryką była dla mnie rodzina i szkoła. Drugą OPOJAZ.

W trzeciej - właśnie trwa obróbka mojej osoby.

A czy my w ogóle wiemy, jak powinna odbywać się obróbka człowieka?

Być może słusznie zmusza się go, żeby stał za kasą. Być może słusznie odcina się go od pracy w zawodzie.

Mówię to głosem swoim, a nie słonika.

Czas nie może się mylić, czas nie może poczuwać się do winy przede mną.

Nie należy mówić: „cała kompania myli krok, jeden chorąży maszeru-

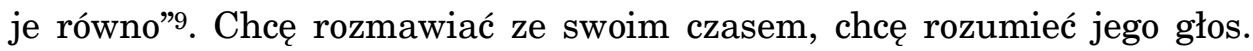
Tylko teraz trudno mi pisać, bo rychło osiągnę standardowy rozmiar artykułu.

A sztuka potrzebuje przypadkowości. Objętość książki zawsze wyznaczano autorowi.

Rynek udzielał pisarzowi głosu.

Dzieło literackie żyje materiałem. Don Kichota i Młodzika stworzyło zniewolenie.

Konieczność włączenia do dzieła narzuconego materiału i w ogóle zniewolenie - to źródła twórczości. Ale ja potrzebuję swobody konstruowania. Swobodnego opracowywania materiału. Nie chcę jedynie wykuwać z kamienia krzeseł wiedeńskich. Potrzebuję teraz czasu i czytelnika.

cach” [cyt. w przekładzie J. Tuwima]. Ejchenbaum interesował się muzyką klasyczną, grał na skrzypcach i innych instrumentach. Jak sam wspominał, przez długi czas dręczył go „konflikt między miłością do muzyki i literatury”.

7 Fragment poematu - „dziennika wierszem” Nikołaja Asiejewa Dygresja liryczna (1924).

8 Trzecia Fabryka (od 1926 r. „Pierwsze atelier kinofabryki Sowkino”) mieściła się przy Pierwszym Brianskim Pierieułku 11.

${ }^{9}$ Niedokładny cytat z powieści A. Kuprina Pojedynek (1905). 
Chcę pisać o zniewoleniu, o książkowych honorariach Smirdina ${ }^{10}$, o wpływie czasopism na literaturę, o trzeciej fabryce - o życiu. My (OPOJAZ) nie jesteśmy tchórzami, nie zdmuchnie nas byle wietrzyk. Kochamy wicher rewolucji. Przy prędkości 100 wiorst na godzinę czuć ciśnienie powietrza. Kiedy samochód zwalnia do 76, to ciśnienie się zmniejsza. Nie da się tego wytrzymać. Próżnia wsysa. Dodajcie gazu.

I pozwólcie mi uprawiać nietypowe kultury. Nie jest dobrze, kiedy wszyscy sieją pszenicę. Nie umiem mówić, piszcząc jak słonik.

Kuratela nad sztuką nie jest rzeczą słuszną. Nie po drodze nam z obrzezanym na złoto Abramem Efrosem ${ }^{11}$.

To prawie wszystko.

\section{DZIECIŃSTWO CZŁOWIEKA, KTÓRY POTEM PISAŁ ZWIĘŹLE}

W nocy, majacząc, jak zawsze szukałem wrogów w pokoju, płakałem. Nastał ranek.

Miałem na sobie szarą bluzeczkę (nie lubię tego słowa) z wszytą na dole gumką. Letnia czapka też na gumce. Gryzłem tę gumkę. Moje pończochy też miały gumki, czerwone.

W naszej rodzinie nie było rowerów, psów. Kiedyś trzymaliśmy przy piecu kurczęta, które za późno się wylęgły. Chorowały na krzywicę, leczyłem je pociętym papierem.

Miałem jeszcze, ale znacznie później, ptaszka, w drewnianej klatce. Śpiewał swoją pieśń od szóstej rano, a ja budziłem się o ósmej. Potem zjadł go szczur ${ }^{12}$.

Jestem już stary. Kiedy byłem małym chłopcem, ludzie jeszcze wpadali pod tramwaje konne. Tramwaje były jednokonne i dwukonne.

Za moich czasów doprowadzono elektryczność. Jeszcze raczkowała i paliła się na żółto. Za moich czasów pojawił się telefon.

10 Plany Szkłowskiego spełniły się tylko częściowo. Wydawca A.F. Smirdin (17951857) jako pierwszy w Rosji zdecydował się na wypłacanie autorskich honorariów. Sam Szkłowski nie interesował się zbytnio ta tematyka; polityce honorariów Smirdina została poświęcona praca młodszych formalistów (T. Grica, W. Trenina i M. Nikitina) Stowiesnost' $i$ kommiercyja (Piśmiennictwo i komercja, 1929).

11 [Aluzja do Abrama Markowicza Efrosa (1888-1954), krytyka i znawcy sztuki. W oryginale - gra słów: zołotoj obriez to złocone brzegi kartek w eleganckich, luksusowych wydaniach książek, a „obriezanije” to obrzezanie.]

12 [W oryginale pojawia się nazwa gatunkowa: łuskowiec (ros. szczur). To niewielki ptak z północnej Europy i Azji o ładnym, czerwonawym ubarwieniu. Do Polski przylatuje sporadycznie i w związku z tym jest bardzo mało znany (dlatego zastąpiłam jego nazwę słowem ptaszek). Dla polskiego czytelnika będzie zapewne zabawne, że ptak, który po rosyjsku nazywa się szczur, zostaje zjedzony przez „prawdziwego” szczura (ros. krysa).] 
Za moich czasów zaczęli bić studentów. Natomiast robotnicy mieszkali tak daleko, że u nas na Nadieżdinskiej ${ }^{13}$, niewiele się wiedziało o ich istnieniu. Można było dojechać do nich tramwajem konnym.

Pamiętam wojnę anglo-burską i hektografowany ${ }^{14}$ obrazek: Bur wykańcza Anglika. Przybycie Francuzów do Petersburga ${ }^{15}$. Początek XX wieku. Lodołamacze na Newie.

Mój dziadek był ogrodnikiem w Smolnym. Siwym, rosłym Niemcem. W jego pokoju stała niebieska szklana cukiernica i inne przedmioty, przykryte ciemnym kretonem. Tuż za jego domem wyginała się Newa, pływało po niej coś kolorowego i małego.

Nie mogę sobie przypomnieć, co.

Nie znosiłem, jak mi rozpinali i zapinali guziki.

Dorośli uczyli mnie czytać na klockach, nie miały obrazków. Rogi kubików były w drzazgach. Pamiętam literę „A" na klocku. Nawet dzisiaj bym ją rozpoznał. Pamiętam na zębach smak zielonego, żelaznego wiaderka. W ogóle pamiętam smaki zabawek. Rozczarowania.

Spacerowaliśmy po małym skwerku przy cerkwi Kosmy i Damiana ${ }^{16}$. Mówiliśmy: „Kosmy i orangutana”. Za murem placu widać było szopę. Uważaliśmy, że mieszkają tam małpy... Na szopie był komin. Dorośli się złościli.

Byliśmy zdziczali i niewychowani. Dorośli nie nadążali za nami. Oni to w ogóle nie nadążają. Pamiętam wierszyk:

\section{Doktór Wiktór \\ Fest kuruje \\ Terpentyna \\ Nos smaruje.}

Szalała odra. Jednym dawali kisiel mleczny, innym - jagodowy. Zachorowało u nas czworo dzieci naraz.

Przy ulicy Bassiejnej stały jeszcze drewniane budynki. Wtedy jeszcze wszyscy w mieście się cieszyli, kiedy wycinano sady. Byliśmy jak prawdziwi miastowi.

${ }^{13}$ Nadieżdinska - w okresie komunistycznym ulica Majakowskiego; znajduje się w centrum Petersburga, niedaleko Litiejnego Prospektu; Szkłowscy mieszkali przy ulicy Nadieżdinskiej pod numerem 33.

14 [Tzn. wykonany za pomocą hektografu - powielacza, wykonującego odbitki na woskowej kalce.]

15 Wizyta francuskiego prezydenta Félixa Françoisa Faure’a złożona w 1897 roku.

16 Świątynia batalionu saperów lejbgwardii na rogu ulicy Kirocznej i Kosmodemianskiego (Melitopolskiego) Pierieułka; została zburzona pod koniec lat czterdziestych. 
Ukazywała się jeszcze „Niwa”17 w czerwonych, pozłacanych oprawach. A w niej obrazki: wyścigi na drezynach. Rower został już wynaleziony, ludzie byli z niego tak dumni, jak my dzisiaj z teorii względności.

Na skraju miasta za Newą, od której wiało, znajdowała się Wyspa Wasiljewska - tam, w brązowym domu, mieszkał wuj Anatolij18. Jechało się do niego jakieś półtorej godziny. Wuj miał telefon, a na Wielkanoc częstował pozłacanymi, ale bardzo niesmacznymi jajkami i ciemnoniebieskimi rodzynkami.

A na stoliku jego niezbyt wysokiej żony stało potrójne lustro i różowa świnka skarbonka. Dla mnie ona wtedy była na końcu świata.

\section{DACZA}

Rodzice powoli meblowali mieszkanie, dorabiali się. Kupili ciężkie srebrne łyżki. Oszklony regał. Mosiężne kandelabry. Obili meble czerwonym pluszem. W tamtym czasie wszyscy kupowali dacze.

Tata kupił daczę nad brzegiem morza. Na kredyt. Ziemia tam była piaszczysta, ale i z kawałkami bagna, gdzie rosła osoka; gdzie indziej, na piasku, rosły jałowce. Jałowce rąbaliśmy sami, tępą siekierą. Tata myślał, że na pogrzebie rzuca się jałowiec. A przecież na pogrzebie rzuca się świerczynę.

Jałowiec pokrywa sucha, sinawa kora, a drewno jest twarde jak kość. Nadaje się na trzonki do różnych narzędzi.

Jałowce i sosny rosły rzędami wzdłuż morza. Odgrodziliśmy się w poprzek tych rzędów. Postawiliśmy bramę i przybiliśmy tabliczkę. Z niebiesko-złotymi literami:

\section{Dacza „WYPOCZYNEK”.}

I nastała bieda.

Zmniejszyliśmy liczbę żarówek w pokojach.

Przestaliśmy szyć sobie ubrania. Mama ${ }^{19}$ posiwiała na srebrno. Jest taka po dziś dzień.

Narobiliśmy się z tą daczą. Tata zakładał futro, pracował. Sadziliśmy sosny na piasku wzdłuż ogrodzenia. Teraz są trzy razy wyższe ode mnie. Tak mijały lata.

17 Niezwykle popularny w Rosji tygodnik ilustrowany „Niwa” był wydawany w Petersburgu w latach 1870-1918.

18 Anatolij Władimirowicz Szkłowski, wuj Wiktora Szkłowskiego, przed rewolucją był „kamienicznikiem”, a wcześniej zarządzał majątkiem wybitnego uczonego i męża stanu Pawła Milukowa; po ucieczce ze Związku Radzieckiego Szkłowski przebywał przez jakiś czas w tym majątku.

19 Warwara Karłowna Szkłowska (z domu Bundel; 1864-1948). 
Mama jeździła po ludziach z błaganiem, żeby jeszcze trochę poczekali na oddanie długu. Sprzedawaliśmy meble na aukcjach. Całe morze łez. Dorastałem jako ostatnie dziecko w rodzinie, dojrzewając jak zbyt późno zasiane zboże. Mieszkaliśmy na swojej daczy za miastem. Ogromne okna, za oknami śnieg - i śnieg pokrywający lód aż do samego Kronsztadu. Kra na morzu, nierówna jak asfalt połamany podczas robót drogowych.

\section{RÓŻNEGO RODZAJU GIMNAZJA}

Zimny Piter o szarym poranku. Gimnazjum.

Uczyłem się kiepsko, w kiepskich szkołach. Z początku mieli mnie wysłać do dobrej szkoły - do Trzeciej Realnej. Zdawałem do niej egzamin.

Za szklanymi drzwiami - milczące klasy. „Realiści”20 na swoich miejscach, jak ich palta na wieszakach. Puste korytarze, puste schody, w sali egzaminacyjnej podłoga z płytek w grubą kratkę.

Po parkiecie chodzi drobny staruszek w wicmundurze ${ }^{21}$ - dyrektor realnej, Richter ${ }^{22}$.

Nauka w szkole trwała siedem lat.

Nie zostałem przepuszczony poza salę z kafelkową podłogą, bo pisałem z błędami.

Dostałem się do realnej prywatnej - do Bogińskiego ${ }^{23}$. Tam z góry widać było porośnięty trawą skwerek przy Placu Znamieńskim i zabity deskami ustęp.

Teraz tam stoi pomnik Aleksandra ${ }^{24}$.

Zabrali mnie stamtąd, bo szkoła była bardzo droga.

Odsyłano mnie z gimnazjum do gimnazjum. W rezultacie moje szare palto trzeba było przefarbować na czarno i przyszyć do niego kołnierz $\mathrm{z}$ kociego futra.

Tak właśnie został zrobiony płaszcz ${ }^{25}$.

20 „Realiści” - uczniowie „realnego gimnazjum”, czyli szkoły średniej, w której programie nauczania przeważały przedmioty matematyczno-przyrodnicze. Gimnazja realne powstały jako alternatywa wobec gimnazjów klasycznych, ukierunkowanych filologicznie.

21 [Wicmundur - elegancki, służbowy strój urzędników państwowych w Imperium Rosyjskim.]

22 Prawdopodobnie chodzi o dyrektora trzeciej szkoły realnej (Grieczieskij Prospekt 83).

23 Tzn. do prywatnej realnej szkoły N.W. Bogińskiego (Newski Prospekt 83).

24 Pomnik Aleksandra III, zbudowany według projektu P. Trubieckiego, został wzniesiony w 1909 roku na Placu Znamieńskim przy Dworcu Moskiewskim (w 1937 roku pomnik został rozebrany i umieszczony w Muzeum Rosyjskim; w połowie lat dziewięćdziesiątych postawiono go przy wejściu do Pałacu Marmurowego). (1919).

${ }^{25}$ Aluzja do znanego artykułu B. Ejchenbauma Jak jest zrobiony „Płaszcz” Gogola 
Zacząłem się przygotowywać do egzaminów eksternistycznych. Dużo czytałem, nie paliłem. Włosy miałem już przerzedzone, takie kędziorki.

Heroiczne starania rodziców o to, by uratować daczę, nic nie dały. To nie byli ludzie zaradni. Nadszedł termin spłaty hipoteki - i daczę trzeba było sprzedać.

Sytuacja zaczęła się poprawiać. Znowu kupiliśmy kandelabry i srebra, trochę lżejsze niż poprzednie.

Oblałem egzamin eksternistyczny w korpusie kadetów.

Postanowiono, że jednak muszę się uczyć w gimnazjum. Dla uzyskania pełnych uprawnień trzeba było spędzić co najmniej trzy lata w gimnazjum ${ }^{26}$.

Gimnazjum, do którego poszedłem, dawało uprawnienia i było najgorsze ze wszystkich. Uczęszczali do niego uczniowie wyrzuceni z innych szkół. Zawiadował nim doktor Sz. ${ }^{27}$, człowiek z Archangielska, niepozorny blondyn, niemal pozbawiony oczu i twarzy, w czarnym pogniecionym i wydętym jak balon surducie.

Czerwony słonik mówi bardzo ospale. On chce mówić o miłości.

Ale miłość, jak powiedziała mi Łarisa Reisner ${ }^{28}$ - to sztuka z krótkimi aktami i długimi antraktami. Trzeba wiedzieć, jak się zachowywać w antraktach...

Co zaś tyczy się doktora, o którym teraz piszę, to rozgryzam go niemrawo, jakbym przeżuwał słomę.

Był uczniem Pawłowa, bardzo zdolnym.

Płynę dalej, ubijam wodę łapami, kto wie - może zrobi się z niej gęsta bita śmietana ${ }^{29}$.

${ }^{26}$ Słowa Szkłowskiego dotyczą prawa do studiowania na uniwersytecie, którego absolwenci szkół realnych byli pozbawieni.

$27 \mathrm{~W}$ rękopisie oraz w części zatytułowanej Wiosna i kawałek lata nazwisko podane zostało w pełnym brzmieniu: Szepowalenko; w rzeczywistości chodzi o lekarza wojskowego Nikołaja Pietrowicza Szepowalenkowa (1872-?).

${ }^{28}$ Łarisa Michajłowna Reisner (1895-1926) - urodzona w Lublinie pisarka i publicystka rosyjska, charyzmatyczna działaczka socjalistyczna. Wraz z mężem F. Raskolnikowem, dowódcą floty wołżańskiej, uczestniczyła w misji dyplomatycznej w Afganistanie w 1921 roku. Kochanka komunisty Karola Radka.

${ }^{29}$ Odniesienie do staroindyjskiej przypowieści o żabie, która - znalazłszy się w beczce z mlekiem - ubijała je łapami tak długo, aż z mleka powstało masło. 
Doktor mieszkał z człowiekiem genialnym. Gimnazjum założył dla pieniędzy. Miał najgorszych uczniów. Sam zaś pomiędzy nami był chodzącą mieszaniną nauki i niesumienności. Patrzył na nas nieuważnie, jak sklepikarz handlujący wybrakowanym towarem i przenikliwie jak fizjo$\log$.

To był typowy Rosjanin.

Nikołaj Pietrowicz miał też własne teorie pedagogiczne.

- Aż do piątego roku życia - powiadał - dziecko nie chodzi do szkoły, a dowiaduje się w tym okresie więcej niż przez całe swoje życie.

A poza tym zła szkoła - to jest właśnie dobra szkoła. Jeżeli uczniowie niszczą cynowe kałamarze, to należy dać im szklane - bo ich rozbijanie nie jest już takie zabawne.

Nikołajowi Pietrowiczowi w ogóle było wszystko jedno - trochę lepiej czy trochę gorzej. Patrolował gimnazjum, wściekał się i własnymi rękami wyjmował z pisuarów niedopałki.

Nudził się jak bileter podczas spektaklu albo widz podczas antraktu. letera.

Chcę opowiedzieć o pewnym człowieku - który kochał miłością bi-

Z Ministerstwa Oświaty Ludowej przyjeżdżali do nas inspektorzy okręgowi.

Cała klasa zamierała, uświadamiając sobie własną miernotę. My naprawdę nic nie wiedzieliśmy. Nie nauczyliśmy się ułamków dziesiętnych.

Inspektor okręgowy zaglądał najpierw pod ławki i sprawdzał, czy nie nosimy wysokich butów. Potem rozglądał się po ławkach. Siadał koło jakiegoś ucznia, brał jego zeszyty, kartkował.

Wytrząsał z Horacego karteczki z tłumaczeniami.

Potem szedł do ubikacji szukać niedopałków w pisuarach.

Nauczycieli mieliśmy przeróżnych, często się zmieniali. Byli jak radzieccy służbiści, tylko piętnaście lat wcześniej.

\section{EGZAMIN KOŃCOWY}

Nauka, blada i chuderlawa, przylepiała się do stron książek i za nic nie mogła się z nich wydostać.

Przesiadując $\mathrm{w}$ szarych klasach, popijaliśmy co nieco (jarzębinówkę, a butelki wrzucaliśmy za piec). Graliśmy pod ławkami w oczko. Prawie nic nie czytaliśmy. Ja za to pisałem już prozę i o teorii prozy. To, co nazywa się społeczeństwem, w ogóle do nas nie docierało. Gdybyśmy tylko zechcieli się poprawić, to prawdopodobnie w poczuciu skruchy zaczęlibyśsmy czytać gramatykę łacińską. 
Mieliśmy świetnego łacinnika - starego dyrektora z Archangielska, Kurska, Astrachania i Kutaisi: przepędzano go ze szkoły do szkoły, a on zabierał ze sobą co bardziej narwanych uczniów, wychodząc z założenia, że w końcu muszą gdzieś coś skończyć.

W Wołogdzie, skąd pochodził, cieszył się wielką sympatią. Statki i łódki omijały szerokim łukiem brzegi, przy których łowił ryby.

Od niego dowiedziałem się o ut consecutivum ${ }^{30}$.

Samochody ślizgały się po elewacjach koło gimnazjum niczym po piersi fortepianu; jak struny drgały przewody tramwajowe. Ponad Newą było widać, jak na zielonej siatce czernieje parkan Ogrodu Letniego.

Ogród Letni.

Ogród zaczynał się zazieleniać. Wiosna, niczym wiatr, właziła pod płaszcz, za pazuchę.

W wielkiej sali porozsadzali nas, każdy był oddalony o sążeń ${ }^{31}$ od najbliższego sąsiada. Zaczęły się egzaminy.

Ściągaliśmy, podpowiadaliśmy sobie i chyba nie porozumiewaliśmy się tylko sygnałami Morse'a.

Między ławkami chodzili pobłażliwi nauczyciele. Napisałem na egzaminie szesnaście prac.

Jeden z kolegów zasnął w oczekiwaniu na swoją. Obudził go któryś z tyłu:

- Waśka, nie śpij, pisz.

- Zaraz mi napiszą - odpowiedział łaskawie i spał dalej.

A łacińskie wiersze ten niebieskooki i przystojny młodzian odczytał z tego, co trzymał w rękach inspektor okręgowy.

Dała o sobie znać sztuka stawiania wszystkiego na głowie.

Gdzie wy się podziewacie, przyjaciele?

Gdzie się podziewasz, Klimowiecki, Jenisiewski? Mówią, że został zabity podczas obrony Carycyna ${ }^{32}$. A gdzie Tarasow? O Bruku wiem wszystko.

Surowcew jest lotnikiem. Jak się spotkamy, to będzie nam przykro, że tak bardzo się zestarzeliśmy. Nie warto robić takich spotkań.

A to wszystko działo się naprzeciwko liceum przy Kamiennoostrow$\operatorname{skim}^{33} \ldots$

30 [W gramatyce łacińskiej: zdanie skutkowe, którego poprawność wymaga spełnienia określonych reguł.]

31 [Sążeń - dawna miara długości, około 2 metrów.]

32 Dalej w rękopisie: „To nie koledzy z ławki cię zaatakowali”. Chodzi o obronę Carycyna przed ofensywą kozaków dońskich dowodzonych przez „białego” generała Piotra Krasnowa od lipca 1918 do lutego 1919 roku.

${ }^{33}$ Od 1844 roku Liceum Aleksandrowskie - dawne Carskosielskie - mieściło się przy Prospekcie Kamiennoostrowskim 21 (na początku XX wieku była to jedna z najbardziej eleganckich ulic Petersburga). 


\section{DŁUG WOBEC MOJEGO NAUCZYCIELA}

Najlepiej zdałem egzamin z religii. Przez przypadek znałem historię Kościoła z kursów akademickich. Teraz też piszę z błędami. I z tego powodu po egzaminie $\mathrm{z}$ rosyjskiego poszedłem do domu mojego wykładowcy. To był stary nauczyciel z grona privat-docentów, chodził kiedyś na wykłady Potebni ${ }^{34}$ - oznaczało to, że zamienił prawdziwą naukę na służbę państwową, tylko że ta służba okazała się porażką.

To go złamało.

Poszedłem do niego po zmroku. Nacisnąłem dzwonek. Osobiście otworzył mi drzwi. Ubrany był w wicmundur, a na jego szyi, zdaje się, wisiał order.

- Przyszedł pan. Pana praca leży u mnie na biurku. Czy przyniósł pan atrament $\mathrm{z}$ gimnazjum?

- Nie przyniosłem.

- To nic, sam przygotowałem.

I w głębokiej nocy przy ulicy Gularnej poprawiałem swoje błędy w podziemiu.

- Za to Pan, Panie Szkłowski - powiedział do mnie nauczyciel - poświęci mi swoją pracę magisterską.

Do tej pory nie napisałem swojej pracy magisterskiej ${ }^{35}$.

Ale to właśnie miejsce w mojej pracy, bynajmniej nie magisterskiej, poświęcam panu, mój stary nauczycielu...

Zlitował się pan nad moim „ち”36.

\section{PISZE O POCAŁUNKACH}

Kochała mnie i nie zadręczała. Całowaliśmy się bez wielkiej wprawy.

A raz całowaliśmy się do samego rana, gdy nagle coś czerwonego uderzyło w okno, dziewczyna aż krzyknęła. To był carski dzieńn ${ }^{37}$ i wiatr

34 Ołeksandr Afanasjewicz Potebnia (1835-1891) - filolog, członek-korespondent Akademii Nauk; jego prace miały bezpośredni wpływ na tzw. szkołę formalną.

${ }^{35} \mathrm{Na}$ początku XX wieku w Rosji studenci pisali pracę, by otrzymać tytuł magistra. Wówczas był to stopień naukowy pomiędzy kandydatem nauk (przyznawanym wszystkim absolwentom uniwersytetów, którzy obronili swoją pracę dyplomową) a doktorem.

36 [Ta litera to tzw. jat', kłopotliwa ortograficznie. Pierwsze projekty jej likwidacji powstały w drugiej połowie XIX wieku. Ostatecznie w 1917 roku Rząd Tymczasowy wydał dekret o reformie zasad pisowni, w której zlikwidowano twarde znaki na końcach wyrazów, literę $i$ (z kropką) oraz jat'. Po rewolucji litera stała się symbolem świata przedrewolucyjnego.]

${ }^{37}$ Carskie dni - święta państwowe, podczas których na domach były wywieszane flagi państwowe (czerwony pasek był na dole flagi). 
przewrócił flagę wprost na nasze okno, wybierając przy tym jej dolny pasek.

Wstawało słońce.

$\mathrm{Z}$ rana ulice są puste, mosty podniesione, a słońce wstaje za krzyżami na prawym brzegu Newy.

Spałem niewiele, czasami mdlałem. Dobrze jest kochać kobietę i kapelusz, który nosi, pamiętać ją przez dwanaście czy piętnaście lat.

\section{JESZCZE COŚ O PIERWSZEJ FABRYCE}

$\mathrm{Z}$ uniwersytetu najlepiej pamiętam korytarz. Patrząc $\mathrm{z}$ jednego końca, miało się wrażenie, że człowiek stojący na drugim końcu jest maleńki. Korytarz był ciepły i wypełniony światłem. Niestety, jego drzwi już nie wychodziły na Newę. Na końcu korytarza miał swój gabinet prorektor.

$\mathrm{Na}$ ścianach wisiały tablice $\mathrm{z}$ dykty, a na nich karteczki z ogłoszeniami. Wzdłuż korytarza ciągnęły się ciemne pokoje przechodnie, a za nimi mieściły się audytoria.

Uniwersyteckie gabinety i muzea - mówię o fakultecie filologicznym - są małe. Nie jest łatwo dostrzec cech uniwersytetu w samym uniwersytecie. Trudno też odgadnąć, gdzie właściwie uprawia się naukę: w salach obwieszonych kiepskimi portretami uczonych, w ciepłym korytarzu czy w mieszkaniach profesorów.

Uniwersytet był szkołą życia w społeczności: ustawiały się tam najlepiej na świecie zorganizowane kolejki, wedle zapisywanych na osobnych listach nazwisk. Gotów jestem wierzyć, że to stąd przeniósł się na Ruś zwyczaj ustawiania się w kolejkach. Ubrany w specjalny kostium: zielone portki i zielony surdut ze złotymi guzikami - przekroczyłem próg uniwersytetu.

Ten surdut tylko raz ukończył uniwersytet ${ }^{38}$ i często tańczył na moim starszym bracie. Mój brat tańczył tak wytrwale, że zegarek rdzewiał $\mathrm{w}$ jego kieszeni, a surdut - nie zmienił się ani na jotę.

Sprzedałem go potem w 1919 roku na Rynku Malcewskim naprzeciwko czerwonego budynku Szpitala Ewangelickiego ${ }^{39}$.

38 Starszy brat Wiktora, Władimir Borisowicz Szkłowski (1889-1937) - filolog, tłumacz Dantego, wykładowca Petersburskiej Akademii Duchownej - ukończył wydział historyczno-filologiczny na Uniwersytecie Petersburskim w 1910 roku.

${ }^{39}$ Kompleks budynków Szpitala Ewangelickiego znajduje się na samym początku Litiejnego Prospektu (dom nr 4). 
Mam nadzieję, że kończy już rabfak ${ }^{40}$.

Chodziłem, słuchałem.

Ale uniwersytet nie przyuczał mnie do mojego fachu. Nie wykładano tam teorii prozy, a ja zajmowałem się nią już podczas studiów.

Jeśli przed śmiercią uda mi się powrócić na chwilkę do moich pasji, jeśli napiszę historię rosyjskiego czasopisma jako formy literackiej i zdążę napisać, jak zostały zrobione Baśnie tysiąca i jednej nocy, jeśli uda mi się jeszcze raz zmienić fach, to być może zostaną wszczęte rozmowy o zawieszeniu mojego portretu w budynku uniwersytetu.

Przyjaciele, powieście mój portret w uniwersyteckim korytarzu, wyburzcie gabinet prorektora, wybijcie okno na Newę i przejeżdżajcie koło mnie na rowerach.

\section{UBIJAM WODE ŁAPAMI}

W ciemnej sali wykładowej wykładał Baudouin de Courtenay ${ }^{41}$, filolog, który odmienił uprawianą naukę, chociaż nie potrafił napisać książki. Tę książkę napisał później Meillet ${ }^{42}$.

$\mathrm{Na}$ pierwszym roku wydziału filologicznego filolog musi zaliczyć grekę, co jest równoznaczne $\mathrm{z}$ umiejętnością przetłumaczenia księgi Ksenofonta.

Oblałem.

W tym czasie pojawili się futuryści.

Ale zanim opowiem o tym, dlaczego tak chętnie wsunąłem sztuczne żółte kwiaty za mankiet swojego surduta, opowiem o tym, jak nie zostałem rzeźbiarzem.

Nie będę ukrywał, że w naszym domu wisiały na ścianach bardzo niedobre obrazy i tylko dziwaczny, okropny i ekstrawagancki gust mojego ojca, który rozbudowywał daczę bez żadnego planu, dopóki starczało mu pieniędzy, ratował nasze mieszkanie przed tym, żeby nie wyglądało ostentacyjnie źle.

Dużo czytałem, ale symbolistów nie znałem.

${ }^{40}$ Tzw. rabfaki (ros. raboczije fakultiety) przygotowywały maturzystów do egzaminów na wyższe uczelnie.

41 Chodzi oczywiście o polskiego językoznawcę, członka rosyjskiej Akademii Nauk, Jana Niecisława Baudouina de Courtenay (1845-1929) [znanego w Rosji jako Iwan Aleksandrowicz de Courtenay].

42 Chodzi o prace francuskiego lingwisty Antoine Meilleta (1866-1936) La méthode comparative en linguistique historique (Metoda porównawcza w językoznawstwie historycznym, 1925; przekład ros. 1954) oraz Le slave commun (Język słowiański, 1924; przekład ros. 1951). 
„Wiesy” przez przypadek widziałem, zaś na okładce „Apollona”43 intrygował mnie człowiek, którego golizna była przesłonięta tylko literkami: „Bądźmy jak Słońce”.

Literki prześwitywały.

\section{BAUDOUIN DE COURTENAY, BŁOK, JAKUBINSKI}

Dzięki futuryzmowi i rzeźbiarstwu można było zrozumieć wiele rzeczy. To wtedy zacząłem pojmować sztukę jak samowystarczalny system. Utwierdzony $\mathrm{w}$ takim przekonaniu przeszedłem przez całą swoją drugą fabrykę. Z 32-stronicową książeczką (Wskrzeszenie słowa) przyszedłem do Baudouina de Courtenay.

To kłótliwy, wybitny starszy pan.

Znalazłem się w mieszkaniu profesorskim pełnym półek. Półki stały przy ścianach i wychodziły aż na środek pokoju. Na półkach stały książki. Cała rzesza książek.

Półki spłonęły potem podczas wielkiej rewolucji, a książki, książki profesorów, rozbiegły się po świecie.

Teraz szukają sobie nowego towarzystwa.

Oprócz książek w pokoju stały osobliwe meble.

Usiadłem przy stole na postawionym z boku krześle.

Krzesła tak się stawia po to, żeby na nich siadali onieśmieleni studenci. Byłem onieśmielony.

Baudouin - król Jerozolimy; tak zresztą napisał kiedyś na wizytówce privat-docenta w Kazaniu. Baudouin albo Baldwin to naprawdę potomek pierwszego króla Jerozolimy.

Wysłuchał mnie i zapoznał z Lwem Jakubinskim ${ }^{44}$.

Tak ciężko pisać książki, Lwie Pietrowiczu! Nie wiesz, jak pisać. Nie wiesz, co.

Eskimosi związują się rzemieniem, przesiadując przy przeręblu wybitym w lodzie przez fokę.

Zimno, trudno wytrzymać.

43 „Wiesy” (1904-1909), „Apollon” (1909-1917) - almanachy, główne organy rosyjskiego symbolizmu. „Goły człowiek” - czytelna dla rówieśników Szkłowskiego ironia: zamiast ascetycznej okładki „Apollona” Szkłowski w istocie opisuje okładkę książki K. Balmonta Bądźmy jak Stońce (1900).

${ }^{44}$ Lew Pietrowicz Jakubinski (1892-1945) - lingwista, uczeń Baudouina de Courtenay. Szkłowski wspomina, że poznali się 8 lutego 1914 roku na wieczorze literackim $O$ nowym stowie. 
O Baudouinie nie za wiele. Przewodniczył spotkaniu i na koniec wygłosił mowę o nauce i demokracji ${ }^{45}$, ale nie był napastliwy.

Zostałem przyjacielem Jakubinskiego. Wiele mnie nauczył.

Jakubinski ma krok niepewny, jest jak cyrkiel, który bojaźliwie rozgina swoje precyzyjnie wykalibrowane nóżki.

Wiele razy się myliłem, Lwie Pietrowiczu, jeszcze wiele razy się pomylę.

Ale przecież nie ma prawdy o kwiatach, jest botanika.

Przeszedłem moją drugą fabrykę, myśląc - czy też, skoro mowa jest o przedmiocie obróbki - doświadczając myśli o wolności.

Teraz interesują mnie zagadnienia granic wolności i deformacji materiału.

Chcę się zmieniać.

Boję się zniewolenia przez negację.

Negowanie tego, co robią inni, związuje nas z nimi. Przyszła wojna i przyszyła mnie do siebie pagonami ochotnika. Rozmawiała ze mną głosem Błoka, stojąc na rogu Sadowej i Inżyniernej.

„Na wojnie nikt nie może myśleć o sobie”. Potem powiedział do mnie: „Niestety, większość ludzkości - to prawicowi eserzy”46.

\section{STRZAŁ ARMATNI NIE ZMIEŚCIŁ SIĘ W DOLINIE WISŁY Y7}

...Wojna wisiała odezwami na murach.

Powołali do wojska mojego brata. Leżał w parszywym żołnierskim namiocie. Mama szukała go i krzyczała:

- Kola, Kola!

45 Jan Baudouin de Courtenay wygłosił swoje przemówienie na słynnym wieczorze $O$ nowym słowie w Szkole Tieniszewa, na którym główną atrakcją miał być wykład Szkłowskiego Wskrzeszenie rzeczy. Wykład wywołał skandal, co poświadcza wielu memuarystów. Według Bieniedikta Liwszyca, ostatnie słowa Baudouina de Courtenay brzmiały: „Wprowadzono mnie w błąd. Przysłano mi zupełnie przyzwoitego młodego człowieka [...], który zapewnił mnie, że wszelkie formy przyzwoitości zostaną zachowane. Widzę jednak, że trafiłem do domu wariatów. Nie pozwolę moim nazwiskiem maskować tej komedii”, B. Liwszyc, Póltoraoki strzelec (1933), przeł. A. Pomorski, Warszawa 1995, s. 169.

46 Świadectwa wskazują na to, że rozmowa odbyła się 14 listopada 1914 roku w drodze do „Bezpańskiego Psa”, kiedy Szkłowski i Błok odprowadzali do wojska poetę Władimira Piasta; partia „lewych” eserów (z którymi sympatyzował później Błok) odseparowała się dopiero jesienią 1917 roku, dlatego słowa Błoka zostały wypowiedziane najprawdopodobniej już po rewolucji październikowej.

47 W rękopisie widnieje dopisek: „To są słowa z dzisiejszego felietonu”. 
Kiedy odeszła, sąsiad spojrzał na brata, oparł się na łokciu i powiedział:

- Kola, tak mi ciebie szkoda.

\section{WOJNA}

Wojna była jeszcze młoda. Ludzie zwierali się ze sobą w ataku. Żołnierze byli jeszcze młodzi. Zwarci, nie mogli zadawać sobie ciosów bagnetami. Walili w głowy kolbami karabinów. Żołnierska litość...

Od uderzenia kolbą pęka czaszka.

W Galicji byli nasi grodowi 48 .

Prostytutki na popijawach wdawały się w dyskusje z naszymi oficerami na temat ewentualnego odrodzenia Austrii. Dyskutujaccy nie zwracali uwagi na to, że są dość dziwnie ubrani.

Coś takiego opisuje Maupassant w Pannie Fifi ${ }^{49}$. U nas wszystko było jakieś brudniejsze, w zakurzonych skórach.

Wojna przeżuwała mnie od niechcenia, jak syty koń słomę, wypadałem z jej pyska.

Wróciłem do Pitra, byłem instruktorem w dywizjonie pancernym. A wcześniej pracowałem w zakładach wojskowych.

Nie raz zaczadziłem się w garażu. Plułem żółtą śliną. Leżałem na śliskiej betonowej posadzce, myłem auta, reperowałem je, czyściłem.

Wojna była już stara. Gazeta popołudniowa niczym nie różniła się od porannej.

\section{DO ROMANA JAKOBSONA}

tłumacza przedstawicielstwa dyplomatycznego ZSRR w Czechosłowacji

Pamiętasz, jak bredziłeś, gdy miałeś tyfus?

Majaczyłeś, że gdzieś zginęła ci głowa. Chorzy na tyfus zawsze tak twierdzą. Bredziłeś, że sądzą cię za zdradę nauki. I że ja skazuję cię na śmierć.

48 [Grodowi (ros. gorodowyje) - do 1917 roku szeregowi pracownicy policji miejskiej w Imperium Rosyjskim, dla zwolenników ugrupowań lewicowych - znienawidzony symbol ustroju carskiego. Podczas rewolucji lutowej grodowi byli pierwszymi ofiarami zbuntowanego tłumu. Zob. J. Gonczarow, Siemiejnyj byt gorodżan Sibirii wtoroj polowiny XIX naczała XX wieka, Barnauł 2004. W niniejszym przekładzie gorodowoj został zastąpiony słowem grodowy, odróżniającym go od polskiego strażnika miejskiego.]

${ }^{49}$ Panna Fifi - nowela Guya de Maupassanta opublikowana po raz pierwszy w 1882 roku w zbiorze o tym samym tytule, której bohaterami są pruscy oficerowie i francuskie prostytutki. 
Majaczyło ci się jeszcze, że Roman Jakobson umarł, ale uchował się zamiast niego chłopiec, na jakiejś głuchej stacji. Chłopiec nie ma o niczym pojęcia, ale to jednak Roma. A rękopisy Jakobsona są palone. Chłopiec nie może pojechać do Moskwy, by je uratować.

Mieszkasz w Pradze, Romanie Jakobsonie.

Od dwóch lat nie ma listów od ciebie. Ja też milczę, jakbym był winny.

Drogi przyjacielu, książka Teoria prozy ${ }^{50}$ została już wydana. Posyłam ci ją.

Pozostała niedokończona. I taką ją wydrukowali.

Ja i ty - byliśmy jak dwa tłoki w jednym cylindrze. To się zdarza w życiu parowozów. Zostałeś odkręcony i trzymają cię w Pradze jako część zapasową.

Drogi Romanie! Po co pracować, skoro nie ma z kim o tym pogadać? Tak bardzo tu mi się cni bez ciebie. Chodzę po redakcjach, dostaję pieniądze, dorabiam w kinie i jestem bliski napisania nowej książki.

Wiesz, Romka - zajmuję się problemem ubezwłasnowolnienia pisarza. Badam ubezwłasnowolnienie jak przyrząd gimnastyczny ${ }^{51}$. Ale tutaj na ulicy są ludzie, i to nic, że przeciekam jak nieszczelna rura, bo ziemia, na którą kapię - to swojska ziemia...

Romanie, dlaczego do mnie nie piszesz? Pamiętam Pragę ${ }^{52}$. Latarnie, które gasiliśmy. Most, przez który nie mogliśmy przejść, bo zabrakło nam pieniędzy.

Wełtawę - rzekę ładnie wydzieloną i pełną pluskających się w niej Czechów. Czeskie piwo w litrowych kuflach. Knedliczki, Sonię Nejman ${ }^{53}$, Piotra Bogatyriewa.

Piwiarnie, do których zachodziliśmy, przemierzając miasto. W jednej - piwo i wodę selcerską, w drugiej - słodki alasz ${ }^{54}$. Sen na oparciu kanapy.

Pamiętasz, o co się pokłóciliśmy? Przecież chyba się nie pokłóciliśmy.

${ }^{50}$ Chodzi o książkę Szkłowskiego O teorii prozy, wydaną w 1925 roku.

${ }^{51}$ Dalej w rękopisie przekreślone nawiązanie do Żywotów równoległych Plutarcha: „A ruda lisica jadła moje kiszki, narzekając, że nie są odpowiednio gorące”.

52 Szkłowski był u Jakobsona w Pradze między sierpniem a wrześniem 1922 roku. Został tam przyjęty niezbyt życzliwie [przez środowiska emigracyjne] (podobnie zresztą jak Jakobson) ze względu na domniemane afiliacje komunistyczne. Szkłowski pisał do żony 25 października: „mieszkałem w Pradze, ale zostałem źle przyjęty - zawyrokowali, że jestem bolszewikiem [...] Teraz jestem w Berlinie z Romą [Romanem Jakobsonem]. Roma chce, żebym został w Pradze. Ale ja zostanę tutaj".

${ }^{53}$ Sonia Nejman - osoba niezidentyfikowana. Raczej nie była to żona czeskiego poety Stanisława Kostki Nejmana (1875-1947), którego wiersze tłumaczył na rosyjski Jakobson. Niewykluczone, że Szkłowski źle zapamiętał nazwisko - pierwszą żonę Jakobsona znajomi nazywali Sofią Nikołajewną (po drugim mężu Gaasową; 1899-1982).

${ }^{54}$ Alasz - mocny likier kminkowy koloru żółtego, popularny w latach dwudziestych. 
Ptaki trzymają się gałązki nawet wtedy, kiedy śpią. Tak powinni się trzymać przyjaciele.

Odpowiedz mi - a ja tobie odpowiem książką55. Jak twoje życie rodzinne? Wiesz, Romka - rodzina to porządna, wciąż jeszcze sprawna maszyna, którą świat postanowił zużyć do końca; żal się jej pozbyć, ale nabywanie nowej nie ma sensu.

A ona ani drgnie. W związku z nią mąż i żona muszą codziennie pokrywać deficyty.

Ona wypełnia cały dom. Pozostaje tylko miejsce pomiędzy oknami obok naczyń z kwasem siarkowym ${ }^{56}$.

Ty, Romanie, jesteś w porządku. Doskonale znasz czeski, dobrze znasz jeszcze wiele innych języków. Nie kupczysz nauką. Ty ją chronisz.

Znasz moje majaki. Ja nie kupczę nauką, ja z nią tańczę. Możesz mnie osądzać, Romanie, ale ja nie objadam się nauką, nie noszę jej jak krawata; to ja ciebie, Romanie, osądzam.

Kiedy siedzieliśmy na kanapie u Osipa, nad kanapą wisiały wiersze Kuzmina. Byłeś wówczas ode mnie młodszy, próbowałem cię nawrócić na nową wiarę. Przyjąłeś ją, całą inercją własnego ciężaru. Teraz znowu jesteś akademikiem. Jest nas coraz mniej. Gubię siebie, jak merynos gubi swoją sierść na kępach ostu.

Och, Romka, ból mnie obudził. Rozbudziłem się.

Cień nie chce mi podać ręki.

Jestem lnem na ścielisku. Patrzę w niebo, czując niebo i ból.

A ty sobie spacerujesz, Romka.

Dwuletnia dziewczynka mówiła o wszystkich, którzy odeszli: „spacerują”. Dzieliła ludzi na dwie kategorie: „są tutaj” albo „poszli na spacer”.

„Tata poszedł na spacer, mama poszła na spacer”.

Zimą zapytaliśmy ją: „A gdzie jest mucha?” - „Mucha poszła na spacer".

A mucha leżała do góry łapkami między ramami okien.

Jesteśmy nieszczęśliwymi ludźmi, Romanie. Łamiemy się jak przeciążone spoiny. Nity zgrzytają w moim sercu i bieleją jak spawalnicze żelazo, kiedy się je wyrywa. A ty jesteś imitatorem. Przecież jesteś rudy powiedz, dlaczego chcesz być akademikiem? Oni są nudni, obchodzą trzechsetlecie. Nieustający, nieśmiertelni ${ }^{57}$.

${ }^{55}$ Być może jest to aluzja do książki $O$ wierszu czeskim (1923) Jakobsona, którą badacz zadedykował Szkłowskiemu: „Wiktorowi Szkłowskiemu - zamiast odpowiedzi na list zamieszczony w piśmie «Kniżnyj Ugoł»".

56 Butelki z kwasem siarkowym stawiało się między wewnętrzną i zewnętrzną ramą okienną, by zapobiec parowaniu okien.

57 Aluzja do świętowanego w 1913 roku trzystulecia dynastii Romanowów i dwustulecia Akademii Nauk obchodzonego w 1925 roku. „Nieśmiertelni” - to zapewne także 
Piszesz prace, w których materiał bierze się sam z siebie. To leśna zagroda, a nie budynek.

Trzeba szukać metody. Znaleźć sposób badania różnego rodzaju ubezwłasnowolnień. A ty jesteś taki przydatny, taki mądry, a w ogóle cię nie ma - zamiast ciebie jest trzystuletni Winokur ${ }^{58}$.

Drugi raz wołam cię, żebyś wrócił do domu ${ }^{59}$. Nie pojadę po ciebie.

\section{O DRUGIEJ FABRYCE}

Lekki, jak człowiek bez nóg, Brik mówił do Ejchenbauma:

„Kiedy aktor zrywa z twarzy maskę - obnaża charakteryzację".

$\mathrm{Z}$ tego właśnie został zrobiony Płaszcz.

Jabłka spadają na ziemię podług prawa ciążenia, nawet w dniu święta rewolucji.

Mięso dobrze się kroi - to znaczy, że porządnie naostrzyliśmy nóż.

Nie wmawiajcie nam, kim jesteśmy. Jesteśmy kamieniami, o które ostrzy się prawdę.

Życie ci nie wychodzi, kiedy zaczynasz myśleć, że ono jest dla ciebie.

Jestem pracownikiem fabryki filmowej. A miałem posadę $\mathrm{w}$ „Lnocentrum"60.

Włókno się nie urywa, tylko zwija w kształt numeru 33. Tyle mam lat.

Nie odcinam się od swojego czasu. Chcę go zrozumieć - po co jestem mu potrzebny i jak on się ma do mojej pracy?

Życie.

Czasem robią zdjęcia do jakiegoś filmu. Robią zdjęcia, wykosztują się, a film się nie klei, nie daje się zmontować.

Plany ogólne często nie dają się pogodzić ze zbliżeniami ${ }^{61}$. Akcji nie ma - zostały same przejścia.

ironiczna aluzja do honorowego tytułu członków Akademii Francuskiej, używanego od XVII wieku.

58 Grigorij Osipowicz Winokur (1896-1947) - lingwista. W 1924 roku, jak sam pisał, „przeżył wielkie rozczarowanie «futuryzmem» $\mathrm{i}$ «formalizmem»", co odbiło się echem w jego pracach z połowy lat dwudziestych.

59 Szkłowski ma na myśli List do Romana Jakobsona.

60 „Lnocentrum” (Centralna Kompania Plantatorów) powstało w 1915 roku. Swoją pracę w tej ogromnej instytucji Szkłowski opisał w cyklu szkiców Przebiegi i przeloty w książce Hamburski przelicznik (1928), wcześniej publikowanych w piśmie „Len i konopie”.

61 [W oryginale - nieprzetłumaczalna gra słów: zderzenie obiegowych znaczeń słów z terminologią kinematograficzną. Obszczij plan (dosł. „plan ogólny”) to w filmie „ujęcie panoramiczne”, zaś krupnyj plan (dosł. „wielki plan”) to „ujęcie z bliska”, „zbliżenie”.] 
Jeśli słaba szkoła to dobra szkoła - pierwsza fabryka była dobra.

Drugiej - oddaliśmy swoją pracę i życie.

Na włókno - czy na ziarno zostaliśmy zasiani?

\section{LIST DO TYNIANOWA}

Mój miły Jurij, napisałem ten list do ciebie nie przed chwilą, ale ubiegłej zimy: listy te oznaczają tu zimę.

Zacznę nie od tego, co istotne, ale od tego, kto utył i kto gra na skrzypcach.

Utyłem ja. Jest noc. Przekroczyłem już próg zmęczenia i przeżywam coś, co przypomina natchnienie. Co prawda, w mojej głowie, jak w latarence $\mathrm{z}$ numerem domu, figurują dwie liczby. Pierwsza jednocyfrowa wskazuje, ile potrzebuje pieniędzy. Druga - dwucyfrowa - ile powinienem zapłacić za mieszkanie. Sytuacja jest bardzo poważna, trzeba myśleć - choćby w biegu, ale nie przestawać myśleć. Bardzo mi się podoba twój artykuł o fakcie literackim ${ }^{62}$. To celna uwaga, że pojęcie literatury jest niestabilne. Artykuł bardzo ważny, być może kluczowy. Nie potrafię przytaczać cudzych myśli. Sam napisz mi o wnioskach ze swojego artykułu, a ja napiszę ci o mojej sztuce niewiązania końca z końcem.

Twierdzimy, że dzieło literackie może być analizowane i oceniane bez wychodzenia poza szeregi literackie.

W swoich poprzednich pracach przywołaliśmy wiele przykładów wskazujących, że to, co uważamy za „odbicie”, okazuje się w istocie chwytem stylistycznym. Dowodziliśmy, że dzieło jest konstrukcją całościową. Nie ma w nim materiału niepoddanego konstrukcji. Ale samo pojęcie literatury bezustannie się zmienia. Literatura rozrasta się na swych peryferiach, wchłaniając materiał pozaestetyczny. Ów materiał i te zmiany, którym podlega on przy zetknięciu z materiałem już estetycznie opracowanym, również powinny zostać uwzględnione.

Literatura żyje, pochłaniając zjawiska nieliterackie. Ale forma artystyczna to osobliwy przypadek porwania Sabinek ${ }^{63}$. Materiał przestaje rozpoznawać swojego posiadacza. Został poddany obróbce zgodnie z regułami sztuki i może już być odbierany w oderwaniu od źródła swego po-

62 Chodzi o artykuł Tynianowa O fakcie literackim z 1924 roku, który autor dedykował Wiktorowi Szkłowskiemu. W kolejnych latach artykuł był wznawiany pod tytułem Fakt literacki. [W języku polskim w zbiorze: J. Tynianow, Fakt literacki, wyb. E. Korpała-Kirszak, przeł. E. Feliksiak, Warszawa 1978.]

${ }^{63}$ Nawiązanie do legendy, opisującej porwanie kobiet z plemienia Sabinów przez nieżonatych mężczyzn podczas igrzysk zorganizowanych w Rzymie przez Romulusa. 
chodzenia. Jeśli to niezrozumiałe, zaraz wytłumaczę. Sztuka w relacji do życia dysponuje kilkoma rodzajami wolności: 1) wolnością nierozpoznawania, 2) wolnością wyboru, 3) wolnością przeżywania (fakt zostaje zachowany w sztuce, chociaż z życia już zniknął). Sztuka wykorzystuje jakości przedmiotów do tworzenia przeżywanej formy.

Trudna sytuacja pisarzy proletariackich wiąże się z tym, że chcą wepchnąć na ekran jakieś rzeczy niedostosowanych rozmiarów.

Co się tyczy mnie, to utyłem. Boris nadal gra na skrzypcach. Ciągle kiksuje. Pierwszy kiks - charakterystyczny także dla moich prac - to niedocenianie znaczenia szeregów pozaestetycznych.

Całkowicie błędne jest również wykorzystywanie dzienników do objaśniania genezy dzieł sztuki ${ }^{64}$. Czai się w nich ukryte kłamstwo - że pisarz tworzy i pisze sam, a nie razem ze swoim gatunkiem, z tradycją literacką i wszystkimi zwalczającymi się w niej prądami. Monografia pisarza to zadanie $\mathrm{z}$ rodzaju niemożliwych. Poza tym dzienniki prowadzą nas w stronę psychologii twórczości i „laboratorium geniuszu”. A nam potrzebna jest rzecz.

Stosunek pomiędzy rzeczą a twórcą jest także niefunkcjonalny. Sztuka ma w stosunku do pisarza trzy rodzaje wolności: 1) wolność nieprzywłaszczania sobie jego osobowości, 2) wolność wyboru w obrębie jego osobowości, 3) wolność wyboru każdego innego materiału. Nie należy studiować związków problematycznych, tylko fakty. Należy pisać nie o Tołstoju, lecz o Wojnie i pokoju. Pokaż Borisowi list, ja już z nim to wszystko obgadałem. Odpowiedz mi, ale nie wciągaj mnie w historię literatury. Będziemy zajmować się sztuką. Zrozumiawszy, że wszystko, co jest w niej naprawdę wielkie, jest wielkie dla historii.

PS Moje życie prywatne przypomina próbę odgrzania porcji lodów.

\section{LIST DO BORISA EJCHENBAUMA}

Napiszę ci o skazie. Ty go określasz jako nastawienie na słowo mówione ${ }^{65}$.

Ale jeśli nawet masz rację, to czy w ogóle można rozpatrywać skaz w oderwaniu od sjużetu? Brygadier Gerard Conan Doyle'a66 został zbu-

64 Ejchenbaum wykorzystywał dzienniki, m.in. pisząc wielotomową monografię Lwa Tołstoja.

65 Chodzi o artykuły Ejchenbauma Jak jest zrobiony „Płaszcz” Gogola (1919), Iluzja skazu (1918), Leskow $i$ proza wspótczesna (opublikowany w 1927 roku, ale pisany już w roku 1923). [Skaz - specyficzny typ narracji, naśladujący wypowiedź ustną, skierowaną do określonego słuchacza, którym może być sam opowiadający.]

66 W wersji polskiej Przygody brygadiera Gerarda. 
dowany na dwóch planach: 1) opowieści o czynach bohaterskich, 2) parodii opowiadań, których motywacją jest skaz. Wszystkie heroiczne czyny okazują się nieporozumieniem. Opowiadacz jest autorowi potrzebny do wprowadzenia ironii. To samo widzimy w Pchle Leskowa ${ }^{67}$. Tę rzecz spina stwierdzenie, że podkuta pchła już nie tańczy. Skaz umożliwia inne, ironiczne odczytanie rzeczy na pozór patriotycznej. Zatem skaz jest w każdym razie często - chwytem sjużetu i nie może być rozpatrywany poza nim. Skaz także (często) stanowi podstawę systemu obrazowania. Skaz przerabia sjużet, przekształcając pierwotny plan w jeden z komponentów sjużetu. Ale tu nie chodzi o skaz. I nie o granice podziałów. Nie ma metrum, nie ma rytmu, nie ma obrazów, jest proces. Wypowiadam się nieprecyzyjnie. Ale w całej naszej pracy skupiamy się na zbieraniu chwytów, na tym, w czym nie ma materii i energii, albo przynajmniej na tym, co stanowi ekwiwalent cieplny jednostki pracy. Winogradow ${ }^{68}$ tego nie rozumie.

\section{Notatka objaśniająca}

Dlaczego dołączam tutaj ten list.

Kopenhaga to jedno z duńskich miast. Mieszkał tam Andersen. Kraj jest tak malutki, że na kolei kupuje się tam tylko połówkę biletu.

Wtedy dopiero wymieniali tam latarnie $\mathrm{z}$ tranem na gazowe.

„Jak najdalej, na Boga, jak najdalej od latarni! - pisał Gogol w swojej słynnej noweli Newski Prospekt - omijajcie je jak najszybciej, omijajcie! Szczęście, jeśli się wykpicie tym, że latarnia zakapie wasz elegancki surdut swym cuchnącym olejem"69.

A jednak latarnie były mimo wszystko romantykami. Szczególnie, kiedy zamienili je na gazowe ${ }^{70}$. Emerytowanej latarni gwiazdy zrobiły prezent. Jeśli zapalić w niej woskową świecę, to zamienia się w latarnię magiczną (coś w rodzaju kinematografu).

A deszcz podarował kolejny prezent. „Kiedy wszystko ci się sprzykrzy - powiedział deszcz - będziesz mogła się rozsypać, kiedy tylko sobie zażyczysz"71.

${ }^{67}$ Szkłowski przywołuje opowiadanie N. Leskowa Mańkut: opowieść o tulskim zezowatym mańkucie i o stalowej pchle (1881). [Autorem przekładu polskiego jest J. Tuwim.]

68 Wiktor Władimirowicz Winogradow (1894-1969) - literaturoznawca, członek Akademii Nauk. Winogradow stworzył własną teorię skazu różniącą się od teorii członków OPOJAZ-u.

${ }^{69}$ N. Gogol, Newski Prospekt, [w:] tenże, Opowiadania petersburskie, przeł. J. Wyszomirski, Warszawa 1980, s. 122.

70 Szkłowski przypomina fabułę bajki H.Ch. Andersena Stara uliczna latarnia (1847).

71 W bajce Stara uliczna latarnia kropla deszczu obiecała starej latarni, że na własne życzenie pokryje się rdzą i rozsypie, kiedy zechcą ją oddać na złom. 
Latarnia miała swojego stróża - emerytowanego bohatera pracy. Pokochała stróża i chciała być jego kinematografem. Stróż kochał latarnię i czasem dolewał do niej tranu. Ale po co w ulicznej latarni zapalać świecę?

Latarnia chodziła po redakcjach...

Mówiła: „Nie, nie jestem kinematografem, jestem reflektorem”. Nie, nie potrafię oświetlić pokoju, jestem badaczem...

Moja błyskotliwość już mi się sprzykrzyła. Błyskotliwość to sprzężenie niesprzęgalnego. Jestem w sztuce wynalazcą.

Nie mam gdzie świecić. I oto zapaliłem sobie świecę w środku książki.

Co się zaś tyczy bytu, to on naprawdę określa świadomość.

A w sztuce jest jej często przeciwstawiany. Moją głowę zaprząta codzienność. Najlepsza rzecz w życiu to poranna herbata.

Przecież tak nie można: niektórzy w sztuce przelewają krew i nasienie ${ }^{72}$. A inni się moczą.

Towar przyjmowany jest podług wagi.

\section{LIST DO LWA JAKUBINSKIEGO}

Przyjacielu, nie stanę się ortodoksyjnym marksistą i tobie też nie radzę. W naszym fachu lepiej być wynalazcą niż wyznawcą73. To oczywiście kalambur. Ale co to jest kalambur? To przecięcie dwóch płaszczyzn semantycznych w jednym znaku słownym. Gra polega na odczuciu dysproporcji sensów. Pojawia się także inne myślenie. „Ma pan ładne włosy” - powiedziałem pewnemu dziennikarzowi.

„Nie mam włosów, tylko owłosienie” - odpowiedział.

„Owłosienie" to nieprzyzwoitość, owłosienie nie rośnie na głowie, a ten bezmyślny człowiek nadał temu dubletowi inne znaczenie.

Synonim szuka swojej użyteczności, szuka znaczenia. Porównaj dyskusję o synonimach w Niedorostku Fonwizina ${ }^{74}$. Do podobnej kategorii należą frazy typu: „Dusza nie rozumie ducha”, do niej odnoszą się też uwagi Andrieja Biełego o tym, że „miatiel” i „mietiel” to różne znaczenia tego samego słowa ${ }^{75}$.

72 Być może jest to aluzja do słów W. Rozanowa: „wszystkie moje dzieła zostały zmieszane nie z wodą, nawet nie z olejem, ale z nasieniem ludzkim” (Opadte liście. Kosz drugi i ostatni, 1913).

73 [W oryg. kalambur tworzą słowa: posliedowat' - issledowat'.]

${ }^{74}$ Chodzi o komedię Dienisa Fonwizina Niedorostek. [Sztuka znana w Polsce również pod tytułem Synalek szlachecki.]

75 Za Władimirem Dalem na odrębne znaczenia tych słów wskazywał A. Błok; A. Bieły w swoich wspomnieniach przytoczył zdanie Iwanowa-Razumnika o rozważaniach Błoka na 
U was (u Marra) ${ }^{76}$, zdaje się, też o tym dyskutujecie; waszą myśl można chyba sformułować tak: dublet przyczynia się do powstania nowego pojęcia (w historii języka jest to powszechna reguła). Odpowiedz mi na to. Ale czy to dobrze, że zajęliście się liczebnikami? Przecież system liczb: jeden, dwa, trzy itd. - prawdopodobnie pojawił się później niż pojęcia ,jedno”, „para”, „trójka”. I dalej: to piątka czy trójka ma być podstawa obliczania? Przypomnij sobie podział na ałtyny ${ }^{77}$ - tuziny. Przy liczeniu jajek tuzin nazywa się „wielką setką”, a u seminarzystów (Pomiałowski) „wielka kopa"78 (guzików) to też dwanaście pomnożone przez dwanaście. Porównaj liczenie „grosami”79 i „czterdziestkami” w handlu skórami. „Duża setka”80 to miara oparta na systemie dwunastkowym, chociaż odwołująca się do dziesiętnego.

O co mi chodzi? Zaraz ci powiem. Trzeba badać nie prajęzyk, czy nawet język jako taki, tylko język w jego związku z wytwórczością, przede wszystkim tam, gdzie można mówić o zjawiskach jeszcze żywych. Może to nazbyt zuchwała uwaga ze strony nielingwisty. Zajmujesz się prajęzykiem, ale czy jesteś pewien, że stosunek do słowa, warunki, w jakich się je odbiera, wartość praw nim rządzących same się nie zmieniają? Zmieniają się wszak nie tylko słowa, lecz także stosunek do nich; jestem przekonany, na przykład, że słowo w procesie całego swojego życia przechodzi przez stadium nastawienia na formę i przypadki gramatyczne, i że zanik przypadków był w swoim czasie zjawiskiem ludycznym, czymś w rodzaju zabawnego żargonu.

Mój drogi Lwie, ja też mieszkam na siódmym piętrze i komsomolcy przychodzą do mnie zdyszani. Kotka, spojrzawszy z mojego okna w dół, dostała zawrotu głowy i spadła na jezdnię. Krzywa zmęczenia to dobra rzecz, ona najpierw ogranicza zdolność do pracy, ale po zmęczeniu, zanim nastąpi wycieńczenie, następuje faza natchnienia. Wierzę w twoje natchnienie. Czekam na listy.

ten sam temat. Oba słowa oznaczają w języku rosyjskim zamieć, zawieję, jednak słowo miatiel (od łac. mantellum) oznaczało także rodzaj wierzchniego okrycia męskiego.

${ }^{76} \mathrm{~W} 1925$ roku Jakubinski odszedł z OPOJAZ-u i zaczął pracę nad badaniem liczebnika pod auspicjami twórcy jafetologii, językoznawcy Nikołaja Jakowlewicza Marra (Szkłowski pisze o tym etapie biografii Jakubinskiego niżej). łuszek.]

77 Ałtyn (z tur. altın „złoto”) - historyczna waluta w Rosji. [Dzielił się na 12 tzw. po-

$78 \mathrm{~W}$ pracach N. Pomiałowskiego Mieszczańskie szczęście (1861), Mołotow (1861) i w Szkicach bursy (1862-1863) nie znaleziono podobnej wzmianki.

${ }^{79}$ Gros - 144 sztuki (czyli 12 tuzinów). [Sorok (czterdzieści) - początkowo wyłącznie jako miara liczby skór zwierząt futerkowych (ponieważ na futro dla dorosłego mężczyzny zużywano na ogół 40 skórek soboli.]

80 [120 jaj.] 


\section{O WOLNOŚCI SZTUKI}

Bzdury, jak w bani.

I też takie echo.

Ściany oddają z powrotem to, co powiedziałeś przed chwilą.

Dzisiaj mówi się o wolności sztuki.

Dzisiaj sztuce potrzebny jest materiał.

Boi się kontynuatorów. Pragnie zniszczenia. Inercja sztuki, a więc to, co gwarantuje jej autonomię, dzisiaj już nie jest jej potrzebna.

Przeżywamy w literaturze czarny rok. Nawet bezbrzeżny smutek w pożółkłej łaźni bez wody - w stołówce Domu Hercena ${ }^{81}$ - jest i tak lepszy niż inercja kontynuowania.

Len. To nie reklama. Już nie mam posady w „Lnocentrum”. Teraz bardziej interesuje mnie żywicowanie ${ }^{82}$. Podrzynanie drzew na śmierć. To sposób pozyskiwania terpentyny.

$\mathrm{Z}$ punktu widzenia drzewa to mord rytualny.

Aha, o tym lnie.

Len, gdyby miał głos, krzyczałby przy obróbce. Wyszarpuje się go z ziemi, trzymając za głowę. Z korzeniami. Sieje się go gęsto, żeby uciskał sam siebie, wątły i nierozgałęziony.

Len potrzebuje ucisku. Len jest szarpany. Rozścielany na polach (zawsze w tym samym miejscu) albo moczony w stawach i rzeczkach.

Rzeczki, w których moczy się len - są przeklęte, już prawie nie ma w nich ryb. Potem len się międli i czesze.

Pragnę wolności.

Ale gdy ją znajdę, to pójdę szukać zniewolenia w ramionach kobiety i wydawcy.

A jednak iluzja wyboru - tak jak bokserowi odstęp dwóch kroków - jest pisarzowi potrzebna. Iluzja to dla niego wystarczająco mocny materiał.

Lew Tołstoj pisał do Leonida Andriejewa ${ }^{83:}$ „Myślę, że po pierwsze, pisać trzeba dopiero wtedy, gdy myśl, którą chcesz wyrazić, jest tak na-

81 Posiadłość przy Bulwarze Twerskim 25, gdzie urodził się A. Hercen. Na początku lat dwudziestych posiadłość została sprzedana i przejęta przez organizacje pisarskie.

82 [Szkłowski używa tu omyłkowo - lub, co bardziej prawdopodobne, w wersji dialektalnej - słowa osmot, które dziś określa drewno pochodzące z części podziemnej drzewa, obejmujące także jego pniak pozostały po ścięciu (tzw. karpinę), wykorzystywane do ekstrakcji żywicy. Analogia pomiędzy żywicowaniem a ubojem rytualnym jest niewątpliwa: w jednym i drugim przypadku odbywa się swoiste wykrwawianie żywego organizmu.]

${ }^{83}$ Cytowany list został napisany 2 sierpnia 1908 roku. 
trętna, że dopóki jej nie wyrazisz, to się od ciebie się nie odczepi. Wszystkie inne pobudki pisarstwa, wynikające z próżności, a przede wszystkim te wstrętne, finansowe, jakkolwiek są związane z podstawową kwestią z potrzebą wypowiedzenia się, mogą tylko przeszkadzać szczerości i godności pisarstwa. Tego należy się bardzo obawiać. Druga rzecz to coś, co się często obserwuje i czym, jak mi się wydaje, grzeszą współcześni pisarze (cały dekadentyzm na tym stoi) - to pragnienie bycia kimś wyjątkowym, oryginalnym, pragnienie zadziwienia i zaskoczenia czytelnika. To jest jeszcze szkodliwsze niż te poboczne uwarunkowania, o których pisałem w punkcie pierwszym. Wszystko to wyklucza prostotę. A prostota jest warunkiem koniecznym piękna. To, co jest proste i pozbawione sztuczności, może nie być dobre, ale to, co jest nieproste i sztuczne - nie może być dobre. Trzecia rzecz: pośpiech w pisaniu. Jest szkodliwy, a ponadto oznacza brak prawdziwej potrzeby wypowiadania swoich myśli. Dlatego gdy taka prawdziwa potrzeba istnieje, to piszący nie pożałuje ani wysiłku, ani czasu, by doprowadzić swoją myśl do pełnej jasności i klarowności. Czwarta rzecz to chęć schlebiania gustom i spełniania oczekiwań czytelników danej epoki. To bardzo szkodzi i już na samym początku pozbawia sensu to, co właśnie jest pisane. Sens każdego dzieła sztuki słowa wynika przecież stąd, że nie jest ono nauczaniem w dosłownym znaczeniu, jak kazanie, lecz odsłania ludziom coś nowego - coś, co nie było mi znane, i w znacznej mierze jest przeciwieństwem tego, co w szerokich kręgach uważane jest za oczywistość”.

Mowa jest tutaj, zdawałoby się, o wolności.

Lecz naprawdę chodzi tu nie o wolność, ale o zasadę sprzeciwu.

Dekadenci mocowali się ze swoim materiałem.

Tołstoj wybrał inny materiał.

Jego ideologia, jego tołstoizm - to konstrukcja artystyczna, tworzenie w kontrze wobec oczekiwań epoki.

My dzisiaj nie obrażamy się na Tołstoja, natomiast dla Sałtykowa-Szczedrina Anna Karenina jest powieścią z życia codziennego narządów moczowo-płciowych ${ }^{84}$.

Bez tołstoizmu sam nie mógłby pracować na tym materiale.

Prostota Tołstoja, co dobrze widać w Kozakach, jest negatywna i bierze swój początek w sztuce. W Czerkiesach z kindżałami. W Puszkinie, Lermontowie, Marlińskim.

$84 \mathrm{~W}$ liście do P. Annienkowa z 9 marca 1875 roku Szczedrin nazwał Annę Kareninę „powieścią [...] o zapewnieniu jak najlepszych warunków funkcjonowania organów rodnych [...] Strach pomyśleć, że nadal istnieje możliwość skonstruowania powieści na fundamencie popędów płciowych". 
Przez stobodę lazłem, Swobody nie znalaztem ${ }^{85}$.

Śpiewają tak na wsi. Tak śpiewali. Teraz proponuje się śpiewać o tym, że wszystko jest na swoim miejscu albo że przynajmniej jest miejsce, na którym można wszystko postawić.

Tego u nas w sztuce zrobić nie można.

Ale i to nie znaczy, że jest nam potrzebna wolność sztuki. Lew Tołstoj nie napisałby Wojny $i$ pokoju, jeśliby nie był artylerzystą. Tam u siebie $\mathrm{w}$ domu poruszał się przecież wzdłuż innych linii. Nie wnosząc do utworów elementów przypadku, pozostając płodem kogoś innego, nie zmagając się $\mathrm{z}$ faktem pozaestetycznym, nie można niczego stworzyć.

Zostały dwie drogi. Odejść, okopać się, zarabiać nie na literaturze, a w domu pisać do szuflady.

Jest i taka droga: opisywać życie, sumiennie poszukiwać nowej codzienności i słusznego światopoglądu.

Nie ma trzeciej drogi. I właśnie nią trzeba podążyć. Pisarz nie powinien poruszać się po wytyczonych trasach, jak tramwaj.

Trzecia droga to praca $\mathrm{w}$ gazetach, w czasopismach, codziennie, nie bacząc na siebie, ale, owszem, na pracę; zmienianie się, zmaganie się $\mathrm{z}$ materiałem, zmienianie od nowa, zmaganie $\mathrm{z}$ materiałem, jego ponowna obróbka - i wtedy dopiero powstanie literatura.

W życiu Puszkina jedynie kula Dantesa na pewno nie była poecie potrzebna.

Ale strach i ucisk są potrzebne.

Dziwaczne zajęcie. Biedny len.

Dzieło estetyczne to przecież nie jest zorganizowanie szczęścia, tylko zorganizowanie dzieła. Znów cytat z Tołstoja:

„Rozkosz estetyczna to rozkosz niższego rzędu. I to dlatego wyższa rozkosz estetyczna pozostawia niedosyt. Co więcej, im wyższa jest to rozkosz, tym większe poczucie niedosytu pozostawia. Pragnie się coraz to więcej. I tak bez końca. Całkowite spełnienie może dać tylko dobro moralne. To w nim tkwi całkowite spełnienie - poza nim niczego już się nie chce i nie potrzebuje" 86 .

To Lew Tołstoj.

$85 \mathrm{~W}$ oryg. Po stobodie ja poszot / Tam swobody nie naszot. Stoboda w niektórych językach słowiańskich oznacza wolność, jednak tutaj słowo to odnosi się do budowanych na Rusi w XI-XVIII wieku osad, których mieszkańcy byli przez pewien czas objęci tzw. wolnizną, czyli zwolnieniem z opłat za użytkowanie ziemi pańskiej.

${ }^{86}$ Zapis w dzienniku Tołstoja z 20 lipca 1896 roku. 
Pragnął, tak jak pragną inni, odmiennej estetyki - przyzwalającej, pożytecznej.

Takiej nie było. Ale walka o nią tworzyła nowe utwory.

A te utwory okazywały się całkiem inne. Sztuka poddaje obróbce etykę i światopogląd pisarza, uchylając się od realizacji jego podstawowego zadania.

Rzeczy zmieniają się, znalazłszy się w jej obrębie.

Oto Babel, który podsunął mi pierwszy fragment z Tołstoja; on jest za wolnością.

Jest bardzo utalentowany.

Pamiętam świętej pamięci Dawydowa ${ }^{87}$ występującego w jakiejś komedii. Zdejmował cylinder z głowy tak ostrożnie, żeby nie zepsuć przedziałka.

Tak samo odnosi się Babel do swojego talentu. Nie roztapia się w swoim utworze.

Zmieniajcie biografie. Korzystajcie z życia. Przekładajcie sami siebie przez kolano.

Niech niezmącona pozostanie tylko zimna krew stylisty.

My, teoretycy, musimy znać miejsce przypadku w sztuce.

Przypadek to właśnie dziedzina szeregu pozaestetycznego.

Nie jest przyczynowo związany ze sztuką.

Natomiast sztuka żyje kosztem zmian surowca. Kosztem przypadku. Losu pisarza.

- Po co nabiłeś sobie siniaka na nodze? - zapytał kiedyś Freud swojego syna.

- Na co ci, durniu, ten syfilis? - zapytał jeden człowiek drugiego.

Mnie los potrzebny jest oczywiście do Trzeciej fabryki.

Natomiast chwyty sjużetu sterczą koło moich drzwi jak miedziana sprężyna ze spalonego tapczanu. Wyrobiły się, nie opłaca się już ich naprawiać.

Weźmy dla przykładu dość popularny sjużet: jak jakiś bohater, by dotrzeć do pokoju, w którym przebywa jego ukochana kobieta, pokonuje szereg przeszkód.

Początkowo mamy w tym wypadku sjużet typu wielostopniowego, z nagromadzeniem szeregu utrudnień. Natomiast w późniejszych wariantach ten sjużet już wygląda tak: bohater osiąga swój cel i zasypia ze zmęczenia.

O ile pierwotny schemat można by przedstawić $\mathrm{w}$ postaci wzoru: $a+a 2+a 3$, o tyle następny sjużet jest dwuczłonowy i utrudnienia można

87 Władimir Dawydow (1849-1925) - aktor Teatru Aleksandryjskiego. 
oznaczyć literą „a”, zaś rozwiązanie literą „b”, co znaczy, że pierwotny sjużet zasadzał się na dysproporcji członów równania. W ostatnim wariancie wszystkie zmagania traktowane są jako jedna całość, a dysproporcje sjużetu są efektem niespodziewanego rozwiązania.

Obecnie żyjemy w epoce niedostrzegalności sjużetu jako formy, która wypadła z jasnego pola percepcji, podobnie jak w języku przestała być dostrzegana forma gramatyczna.

\section{PRACA, KTÓRA MI NIE WYCHODZI}

Są długi, które trzeba spłacać. Nadal nie została napisana historia literatury rosyjskiej.

Ale i tak nie ma jej gdzie wydać. Drą z nami koty. A problem nie tkwi w nas, tylko w materiale. W kłótni cała sprawa gdzieś umyka. Kłócą się z nami - i przejmują terminologię. Wprowadzają nierzetelne źródła do podręczników. A my mylimy się we wszystkim oprócz jednej kwestii jesteśmy rzemieślnikami, znamy swój fach i kiedy tylko nam się zechce, to sami napiszemy książkę.

A tymczasem metoda formalna stała się już pokaźną paczką książek. Kolejną szkołą w historii rosyjskiej etnografii. Nie, bynajmniej nie w tym celu łamaliśmy sobie życie o kolano. Nie jesteśmy zbożem jarym, jesteśmy oziminą. Zaraz puścimy kiełki. Umiarkowany wypas bydła nas nie unicestwi.

Ale nie warto silić się na heroizm. Nasza botanika nie domaga się ofiar. Nie jesteśmy marksistami, ale jeśli marksistowskie narzędzia okażą się przydatne w naszej pracy, to nie będziemy na złość jedli rękami.

Czasy są ciężkie dla sztuki, odnowicielskie.

Tramwaj „A” nie jest dla pisarzy. Od Gogola do Gogola88.

Edgar Poe opisał ocean przyszłości - pokryty szczelnie kablami pływającymi na spławikach ${ }^{89}$. Ludzkość wyobrażała sobie przyszłość jako coś lepszego, jako kontynuację. Przyszłość - to rewolucja. W przyszłości nie będzie kłótni o czynsz za mieszkanie.

Lepiej już spalić księgarnie i zakazać druku niż przystać na czerwone odnowicielstwo. Trudno, niechaj sobie nie rozumieją sztuki. Surowiec, z którego powstaje czekolada, nie jest słodki, wydobyta ruda nie dźwięczy, a elektryczność w przewodach nie świeci.

Sztuka, gdy się zmienia, może nie być odczuwalna.

88 W tym czasie moskiewski tramwaj „A” jeździł trasą okrężną, mijając m.in. pomnik Gogola na Placu Arbackim.

89 Wspomnianego dzieła E.A. Poego nie udało się zidentyfikować. 
Żyje mi się nie najlepiej. Jałowo, jak w prezerwatywie. W Moskwie w ogóle nie pracuję. Nocą śnią mi się sny pełne winy. Nie mam czasu na książki.

Sterne, którego ożywiłem, wciąż mnie straszy ${ }^{90}$. Nie tylko produkuję pisarzy, ale sam się stałem takowym.

Pracuję w Trzeciej Fabryce „Goskina” i tnę taśmy filmowe. Całą głowę mam zawaloną kawałkami taśmy. Jak kosz w montażówce. Życie od przypadku do przypadku.

Trochę zepsute. Brakuje siły, żeby przeciwstawić się swojej epoce, może zresztą wcale nie trzeba tego robić. Może to epoka ma rację. Urabiała mnie wedle własnego widzimisię.

W książce angielskiego powieściopisarza z XVII wieku, Smolletta91, znajdujemy rzecz następującą: znajomy bohatera, Anglik, uczy swoich uczniów, także Anglików, nowego niewyraźnego sposobu wymowy. Tak się złożyło, że ta specyficzna artykulacja - sposób wymowy, który jest tak charakterystyczny dla współczesnego języka angielskiego - została przyjęta w Anglii jako określona moda, a więc z powodów estetycznych.

Są podstawy, by sądzić, że francuska wymowa grasejującego „r” powstała w Delfinacie i dopiero stamtąd rozprzestrzeniła się na całą Francję - także jako swego rodzaju moda. Na początku modą był także polski akcent (mający stałe miejsce w słowie) ${ }^{92}$.

Ale skąd się wzięła sama maniera francuskiego „r” albo niewyraźnej wymowy? Dygresja goni u mnie dygresję.

Różnica między szkołą OPOJAZ-u a szkołą Aleksandra Wiesiełowskiego $^{93}$ polega na tym, że Wiesiołowski wyobrażał sobie ewolucję literacką jako niezauważalne nagromadzenie powolnie zmieniających się zjawisk.

90 Szkłowski ma na myśli własne książki artystyczne oraz poświęcony Sternowi artykuł „Tristram Shandy” i teoria powieści (1921, artykuł pod tytułem Powieść ludowa „Tristram Shandy” wszedł do książki Szkłowskiego O teorii prozy).

91 Niedokładny opis epizodu z powieści Tobiasa Smolletta Podróż Humphry’ego Clinkera z 1771 roku.

92 Dociekania Szkłowskiego zainspirowały prace Władimira Szkłowskiego, lingwisty i specjalisty w zakresie filologii romańsko-germańskiej. Władimir Szkłowski w artykule Deklamacja na scenie francuskiej pisał: „grasejujące «r», które wielu Rosjanom wydaje się szczytowym osiągnięciem $\mathrm{w}$ nauce wymowy francuskiej, [...] w wymowie potocznej [...] występowało od XVII stulecia jako fenomen lokalny”.

${ }^{93}$ Aleksandr Nikołajewicz Wiesiełowski (1838-1906) - filolog, akademik, twórca rosyjskiej poetyki historycznej. 
Kiedy Wiesiołowski widzi, że dwa etapy w historii sjużetu różnią się od siebie w dość wyraźnie, to nie mogąc odnaleźć jakiegoś ogniwa pośredniego między nimi, z góry zakłada, że takie ogniwo zaginęło.

Ja zaś twierdzę, że sjużet rozwija się dialektycznie, odpychając się od samego siebie i jak gdyby sam siebie parodiując. Jeśli Wiesiełowski czasem bez mała słusznie - stwierdza, że określony chwyt artystyczny mógł wyłonić się z doświadczenia życiowego, to mnie takie rozstrzygnięcie problemu wydaje się niewystarczające.

Ja bym ujął schematycznie całą sprawę tak: przemiany dzieł sztuki mogą wywoływać i wywołują przyczyny pozaestetyczne, na przykład dlatego, że na dany język wpływa inny język, albo powstało nowe zamówienie społeczne ${ }^{94}$. W taki oto nieuświadomiony i nieumotywowany estetycznie sposób powstaje nowa forma, która dopiero potem jest poddawana ocenie estetycznej, traci jednak swoją pierwotną rangę, swoje znaczenie przedestetyczne.

Wówczas dopiero istniejąca pierwotnie konstrukcja estetyczna przestaje być odczuwalna, tracąc swoje, by tak rzec, przeguby czy złącza, stapia się w jeden kawałek.

\section{DOŚWIADCZENIE, KTÓRE ZDOBYŁEM}

Boję się ustępować swojej epoce. Wszystko dobrze nam pójdzie i nagle się okaże, że godzimy się na: „bez nóg jest wygodniej”95.

Chcę skorzystać z epoki jak z losu. Przywitać ją kulturą swojego fachu - tak, jak spotykają się ze sobą dwie ordy. Żeby powstała nowa mowa.

A tymczasem młodość została wypita. Usta poparzone. Jest fabryka, w której pracuję. Scenariusze, które czytam. I los, przewidywalny na $75 \%$. Czas się przyzwyczaić do życia bez zdarzeń.

Ale i wydarzenia mogą prowadzić człowieka na manowce. Właśnie rozmawiałem z kobietą. Z Ałdanu - przyjechała z Jakucka, żeby się tam rozejrzeć.

Ludzie szli z Ziei ${ }^{96}$ w kierunku Ałdanu. Oroczanie-przewodnicy ${ }^{97}$ ich opuścili. Ludzie strasznie głodowali, jedli liście i szli po dwie wiorsty

94 Pojęcie „zamówienia społecznego” weszło do leksykonu byłych futurystów na początku lat dwudziestych. „Cała ta praca - czytamy w stopce redakcyjnej «LEF-u» - nie jest dla nas celem estetycznym, lecz stanowi laboratorium najpełniejszego wyrażania zdarzeń współczesności. Nie jesteśmy kapłanami-twórcami, lecz mistrzami wykonującymi zamówienie społeczne".

${ }^{95}$ Kolejna aluzja do osoby (a także postawy) O. Brika.

${ }^{96}$ Zieja - miasto w Obwodzie Amurskim.

${ }_{97}$ Oroczanie (Nani) - tunguska grupa etniczna wschodniej Syberii. 
dziennie. Postanowili ciągnąć losy. Było ich wówczas osiemdziesięcioro sześcioro. Jednego postanowili zjeść. Wypadło na młodego Rosjanina. Ale oto umarł na zawał serca stary Tatar. Za bardzo się ucieszył. No to zjedli go.

Potem dotarli do Ałdanu. Dostali po dwa sążnie ziemi. Wycinali las. Płukali złoto. Okazało się, że Ałdan - to harówka.

Nie tylko tamten Tatar ucieszył się na próżno.

Istnieje coś takiego jak doświadczenie. I kobieta, już po tym, jak się z nią kochałeś, patrzy na ciebie i mówi: „dziękuję”. A przecież ja nie powiedziałem jej, że „kocham”.

Ale kurz w tej fabryce.

Trzydzieści sześć jupiterów wisi $\mathrm{w}$ atelier. Cztery pojemniczki z rtęcią̧ ${ }^{98} \mathrm{Z}$ rzadka jakieś zdjęcia. Czekanie na korytarzu. Płytko posadzone życie.

Nie czuć podmuchów wiatru.

Unosi mnie ptak. Karmi się go własnym mięsem ${ }^{99}$. To już przyzwyczajenie. Udko, boczek, cienko krojony. Oddam ci swoje serce, ptaku. Tylko nie dziękuj.

W montażówce fabrycznej pachnie landrynkami. Trzeba jedynie odrobinę zmieniać los taśmy.

Landrynkami pachnie gruszkowa esencja, którą klei się taśmy. Kleją je montażystki. To szkodliwa praca. Nawijają taśmy na nawijarki, taśma biegnie, migają kadry jak sosny w drodze na Ałdan.

Ale ja wiem - mój fach jest mądrzejszy ode mnie.

\section{przełożyła Aleksandra Berkieta przekład przejrzała Danuta Ulicka}

98 W XIX wieku zaczęto wykorzystywać opary rtęci do procesu wywoływania zdjęć, co znacznie skróciło czas ich naświetlania.

${ }^{99}$ Aluzja do motywów popularnych przypowieści ludowych znanych m.in. z Rosyjskich bajek ludowych A. Afanasjewa. 